\title{
Types and Design of Traditional Rehal in the East Coast of Peninsula Malaysia
}

\author{
${ }^{1,2}$ Mohammad Anis Abdul Samad, ${ }^{2} Z$ uliskandar Ramli, ${ }^{2,}$ Mohd Rohaizat Abdul Wahab and \\ ${ }^{2}$ Ros Mahwati Ahmad Zakaria \\ ${ }^{1}$ Academy of Malay Studies, Universiti Malaya, 50603 Kuala Lumpur, Malaysia \\ ${ }^{2}$ Institute of Malay World and Civilization, Universiti Kebangsaan Malaysia, 43600 Bangi, \\ Selangor, Malaysia \\ ${ }^{3}$ Institute for Mathematical Research, Universiti Putra Malaysia, 43400 Serdang, Selangor, Malaysia \\ anis_samad@um.edu.my
}

\begin{abstract}
The love for Qur'an has led to the growth in some segments of Islamic fine arts such as calligraphy, manuscript illumination and binding technology. Not to be left behind, the artistic workmanship of rehal created specifically to hold the holy book also developed further in conjunction with its dispersal to all parts of the world. The dispersion of the rehal led to its diversity in shape, form and ornamentation, indirectly reflecting the artistic identity of the culture ( $\mathrm{s}$ ) behinds its manifestation. This research attempts to identify the distinct characteristics of the traditional rehal in the East Coast of Peninsula Malaysia. The samples of this study were obtained from museum collections, artisans, local mosques and antique collectors. There are three types of rehal found which differ in terms of techniques. They are known as rehal selak, hinged rehal or rehal berjejari and layered rehal or rehal berlapis. Rehal selak make use of a technique known as tanggam which is a joinery technique adopted from Malay architecture. Hinged rehal or rehal berjejari uses hinges that allow the boards to be folded. Layered rehal or rehal berlapis applied sliding technique to open and close the furniture. Several techniques used in rehal making shows the ability of Malay craftsmen in adapting various skills and technology in their works with adjustments and improvements that suits local style.
\end{abstract}

Key words: Rehal, design, East Coast Peninsula Malaysia, technology, ornamentation, Malay craftsmen

\section{INTRODUCTION}

Rehal is also considered as one of the Islamic art. According to Zakaria and Ramli (2016a), Islamic art can mean different things to different people. Even though the concept of rehal as a book stand is universal, however in Islam, the main function of rehal is distinctive. In Islam, rehal is closely related to the sacred book known as the Quran. Most of the Qur'ans from the early period of Islam until today is bound with a leather or a textile cover to protect the sacredness of the Quranic texts written on the pages (Zakaria and Ramli, 201 6b; Zakaria and Ramli, 2018). Due to the status of Qur'an, all matters related to it are considered as important in the Muslim society. It must be handled and kept with all respect. Rehal is one of the main tools used to protect the structure and the beauty of the Qur'an binding.

Rehal is a furniture used to lay the Qur'an which is the holy book for Muslims. Usually, rehal is made from a piece of wood that is halved. At the middle part, there are hinges that allow rehal to be opened when it is to be used and closed when it is to be stored. According to Hughes (1895), rehal is described as:

"A small book stand made, so as to fold up for convenience in travelling but now is generally, used as a book stand in mosques and Muslim schools to support the Quran and other books as the student reads his lesson from them. They are also used in private dwellings"

Meanwhile, Kuhnel (1971) explained rehal as:

"a folding desk for laying out the Koran, became a rich vehicle for the art of carving. It was usually made from one piece into two interlocking leaves and decorated with writing and arabesques, partly in openwork"

Regardless of race, age and rank, Muslims throughout the world used rehal. Basically, the design is almost the same but there is variety in terms of materials,

Corresponding Author: Mohammad Anis Abdul Samad, Academy of Malay Studies, Universiti Malaya, 50603 Kuala Lumpur, Malaysia, anis_samad@um.edu.my 
techniques, sizes and decorations used. This variety indirectly reflects the identity of the art and culture of the society who produce it. Kurz (1972) mentioned:

"Islam brought it to many parts of the world and it had several descendants of its own. Ours was not the only type of lectern used in the Islamic world but certainly the most widespread and the most popular one"

Types of rehal: There are different types of rehal that can be differentiated based on material used, technique applied and dual-function features. In terms of material, the production of rehal often associated with the art of wood-carving. However, there are also rehal made from other substances such as bamboo and concrete. These days, modern rehal made from metal and plastic are also available in the market. Occasionally, there are rehal made with luxury materials such as crystal and jade found in museums collection. Secondly, the design of rehal can be differentiated by the technique applied to open the rehal. There are various techniques, relate to the aptness of material used. Nevertheless, the craftsmen skills also have an influenced on the technique applied. Other than material and technique, modern rehal can also be differentiated by its dual-function features, among which can be used as a small table having a storage box on the bottom as well as several rehal that can be modified into a bag.

The importance of the study: Traditional rehal with local features are gradually disappearing, compared to the imported and modern rehal that are increasingly dominating the local market and seems more popular among the people at large. Without preservation effort, this unique cultural heritage might be lost in time. Therefore, this study attempts to identify the features of traditional rehal from the east coast of the peninsula Malaysia. Discussions in this study will focus on the technical aspects, i.e., material used and technique applied.

\section{MATERIALS AND METHODS}

The samples were collected from 14 local museums and 9 artisans from the east coast of peninsula Malaysia. As a complement, a number of rehal from 5 old mosques visited during the field study were also recorded as well as personal collections from 3 antique collectors. Table 1 shows places visited and the number of rehal documented. The documentation was made by means of still photography, measuring the physical dimension of the rehal and recording any information associated with the particular artefact in question.
Table 1: Places visited and the number of rehal documented

\begin{tabular}{|c|c|c|}
\hline Bil. & Field study place & Amount \\
\hline 1. & Kelantan Islamic Museum & 6 \\
\hline 2. & Terengganu State Museum & 10 \\
\hline 3. & Akademi Nik Rashiddin, Bachok, Kelantan & 6 \\
\hline 4. & Pahang State Museum & 5 \\
\hline 5 . & National Museum, Kuala Lumpur & 10 \\
\hline 6. & Sultan Alam Shah Museum, Selangor & 5 \\
\hline 7. & Museum of Asian Art, University of Malaya & 1 \\
\hline 8. & Islamic Art Museum Malaysia, Kuala Lumpur & 6 \\
\hline 9. & Malay Heritage Museum, Universiti Putra Malay sia & 5 \\
\hline 10. & Malay Ethnographic Museum, University of Malaya & 5 \\
\hline 11. & International Islamic University of Malaysia gallery & 1 \\
\hline 12. & Institut Latihan Perindustrian, Kuala Terengganu & 1 \\
\hline 13. & Perak Museum & 1 \\
\hline 14. & Terradala (Museum and Café), Kuala Terengganu & 1 \\
\hline 15. & Kelantan Woodcaring, Kota Bharu, Kelantan & 6 \\
\hline 16. & Balai Seni Wanpo, Besut, Terengganu & 1 \\
\hline 17. & Bakawali Sari Warisan, Besut, Terengganu & 5 \\
\hline 18. & Pakatan Jurukir Tradisional, Kota Bharu, Kelantan & 2 \\
\hline 19. & Inakraf Woodcaring, Temerloh, Pahang & 2 \\
\hline 20. & Warisan Craft Wood, Temerloh, Pahang & 1 \\
\hline 21. & Alias Ibrahim, Pulau Duy ong, Kuala Terengganu & 1 \\
\hline 22. & Ariffin Ali, Pulau Duyong, Kuala Terengganu & 3 \\
\hline 23. & Muhammad Deraman, Kg. Chendor, Kuantan & 2 \\
\hline 24. & Surau Nibong Pulau Duyong, Kuala Terengganu & 5 \\
\hline 25. & Masjid Tok Ku Paloh, Kuala Terengganu & 3 \\
\hline 26. & Masjid Kg. Tuan, Kemaman & 4 \\
\hline 27. & Masjid Hiliran, Kuala Terengganu & 1 \\
\hline 28. & Masjid Diraja Long Yunus, Langgar, Kota Bharu & 3 \\
\hline 29. & Mr. Tajul Firdaus Tajudin (collector) & 1 \\
\hline 30. & Haji Yahya Abd Rahman (collector) & 1 \\
\hline \multirow[t]{2}{*}{31.} & Dzafar Haji Hanifa (collector) & 1 \\
\hline & Total & 105 \\
\hline
\end{tabular}

From 105 rehal documented, 27 of them came from other countries such as Indonesia, Thailand, India, Pakistan, Iran and Turkey. Only 78 rehal that originated from the East Coast of Peninsula Malaysia were taken as a sample for this study. Samples obtained from selected sources (i.e., museums, artisans, mosques and antique collectors) are expected to provide an overview on the traditional rehal design from the East Coast of Peninsula Malaysia.

\section{RESULTS AND DISCUSSION}

Regarding the species of wood used to make rehal, information was collected from the owner of collection and artisans who produced them. From 78 rehal, only 44 were identified with the species of wood used. Remaining 34 rehal from museum collections and mosques were difficult to be identified, since, they were painted or varnished as well as some samples from the collection of artisans were found in the form of sketches.

From 44 rehal, chengal wood was the most widely used with 25 pieces. This was followed by other local species such as nyatoh (4 pieces), Medang hitam (4 pieces), meranti (4 pieces) and sena (2 pieces). Occasionally, damar hitam (1 piece) and mersawa (1 piece) were used to make rehal. In addition, there are also 


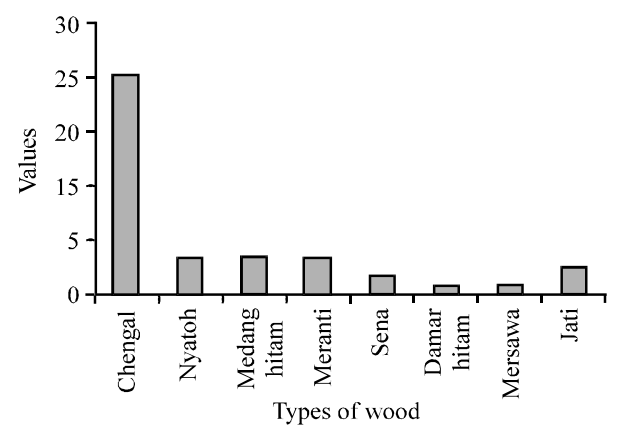

Fig. 1: Species of wood used for rehal production

local artisans using teak wood imported from neighbouring countries (Fig. 1). The results from interviews and literature studies have shown that there are many other species of wood that can be used to make rehal such as merbau, balau, bongor, sepetir, pauh kijang, jelutong and leban and most of the woods are highly graded wood from Malaysia forest which also used to make perahu or traditional boat (Wahab et al., 2018a, b).

Woods differ from one another in terms of density, strength and durability. The uniqueness of colour, vein and grain also has a distinct visual effect between one species and another. In relation to chengal which is the most preferred among local carvers and craftsmen, Ismail and Ahmad explained that the advantages of this wood are it is hard but easy-engraving surface and does not easily cracked during cutting, carving and piercing works. The veins of chengal are overlapped and it has a fine grain. When plated and rubbed, the surface will be shiny. Chengal is also known for its durability and is not easily damaged by fungi and woodworms. With proper usage, buildings or products made from chengal wood can last for hundreds of years for instance, the Telok Manok Mosque in Southern Thailand that is still standing until today although it has reached 300 years. Its quality makes chengal a preferred choice for constructing mosques, houses, boats, agricultural tools, daily necessities and furniture.

Meanwhile, the use of other local timber species such as nyatoh and meranti is also common in furniture making. Besides its availability in the local market, these woods are also preferred for their long lasting quality. There are some types of wood used in furniture making for the beauty of their colour, veins and grain for instance mersawa wood. Additionally, there are several types of wood preferred by woodworkers and carvers for being said to have "spirit"; among them are Medang hitam and sena woods (Noor et al., 2003).

In short, the type of wood is one of the features that can distinguish locally made furniture and abroad.

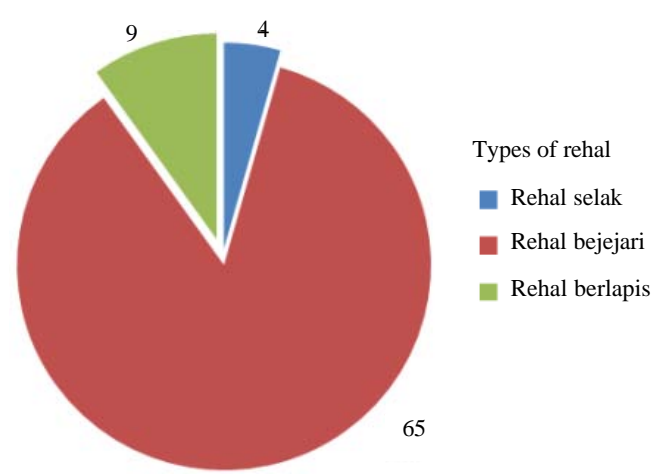

Fig. 2: Number of rehal by type

Although, there are varieties of options, chengal is most widely used in woodworking including in the production of furniture like rehal. In comparison, rehal from India usually use rosewood in Uzbekistan they mostly use walnut while Indonesia is well known for its teak furniture.

Techniques: Since, wood is the most common material used for rehal making on the east coast of peninsula Malaysia, the techniques applied are also compatible with the substances. There are three types of rehal found known as rehal selak, rehal berjejari and rehal berlapis. All three are distinguished by techniques namely rabbet, folding and sliding. From 78 rehals listed in the sample, rehal berjejari was the most abundant by $65(86 \%)$. Meanwhile, only 4 pieces (4\%) rehal selak and 9 pieces (10\%) rehal berjejari were found in this study (Fig. 2) outnumbered.

Latch rehal or rehal selak: In terms of technique, latch rehal or rehal selak is much simple and easy compared to hinged rehal (rehal berjejari) and layered rehal (rehal berlapis). Also known as rehal cantum, rehal selang and rehal selit, it is made using two pieces of board. In the centre of the two slabs is a cleavage that allows both of them to be patched intersecting (Fig. 3). After usage, both pieces can be dismantled and stored in appropriate place.

In the art of Malay woodworking, this temporary joining technique is known as "tanggam" as mentioned in the Ensiklopedia Kraf Malaysia "rehal is produced from two pieces of crossed-boarded panels". The term "tanggam" refers to the joining technique usually used in carpentry. This technique has been practiced by the Malays, especially in constructing houses, mosques and castles. This brilliant idea has become one of the most outstanding innovations in Malay architecture. 


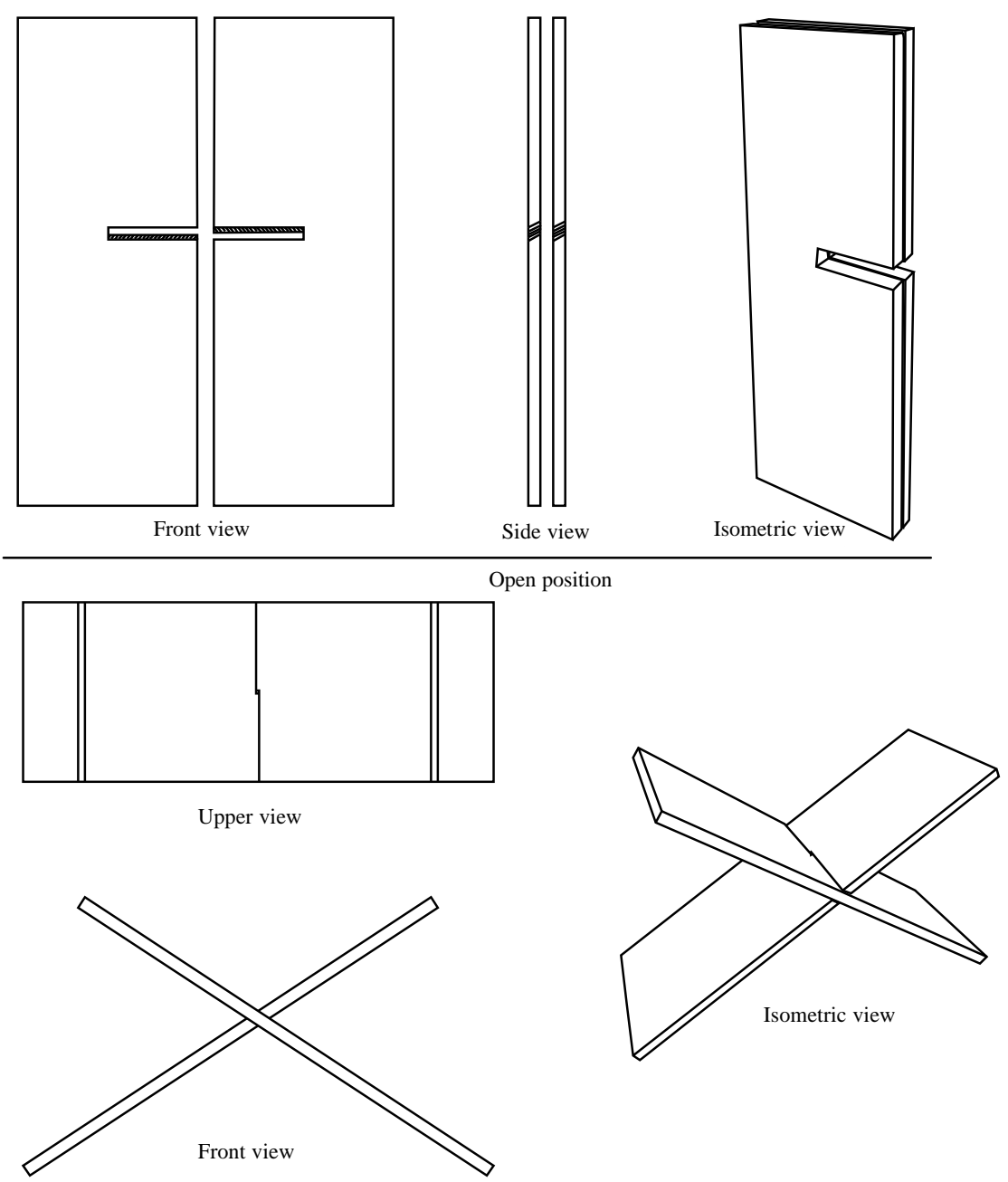

Fig. 3: Illustration of latch rehal or rehal selak

Hinged rehal/rehal berjejari: Another type of rehal is known as hinged rehal or rehal berjejari. The term "jejari" is commonly used among local carvers. It refers to the hinges in the middle part of the rehal. Previous writings also talked about this type of rehal, among them is the study by Kuhnel (1971) who mentioned "It was usually made from one piece into two interlocking leaves". Kurz (1972) also mentioned the rehal "are made of solid wooden boards that move on hinges" while Wohrlin called it a "two-piece Qur'an stand" referring to the similar technique. Hinged rehal or rehal berjejari is made from a piece of board that was halved. When opened, the upper part forms a rehal surface while the lower part become the base of rehal. The centrepiece is made of a joint that combines the slit and allows the rehal to be fold (Fig. 4).

Layered rehal or rehal berlapis: In addition to the techniques discussed above, rehal can also be opened with sliding technique. Among the local carvers, there is another type of rehal which is known as layered rehal or "rehal berlapis" as it is made of a piece of wood split into four layers but still remain as a single unit. When opened by sliding the layers, two of them will turn out to be the base for the rehal, while another two will form its surface. All the opened layers will be interlocked each other in the middle (Fig. 5). During this study, 9 layered rehal or rehal berlapis found in the collection of the National Museum, Terengganu State Museum, Malay Ethnographic Museum, Mr. Muhammad Deraman and Mr. Ariffin Ali. One of layered rehal in National Museum's collection (registration number E49.1967) shows the artefacts was acquired from Kemaman, Terengganu in 1967. This indicates that layered rehal or rehal berlapis has been made and used by the locals for at least half a century ago. 
J. Eng. Applied Sci., 14 (24): 9626-9631, 2019

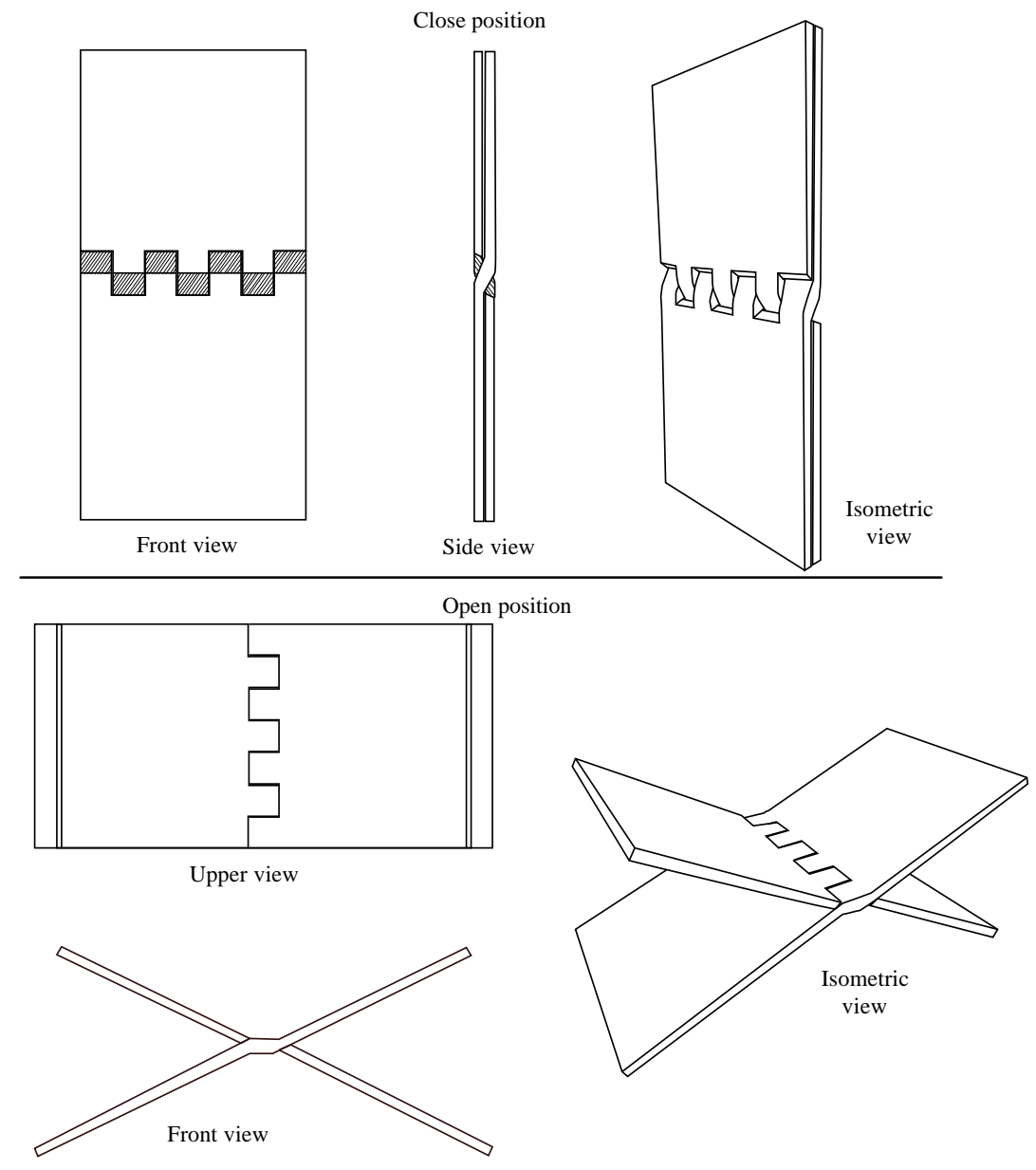

Fig. 4: Illustration of hinged rehal or rehal berjejari
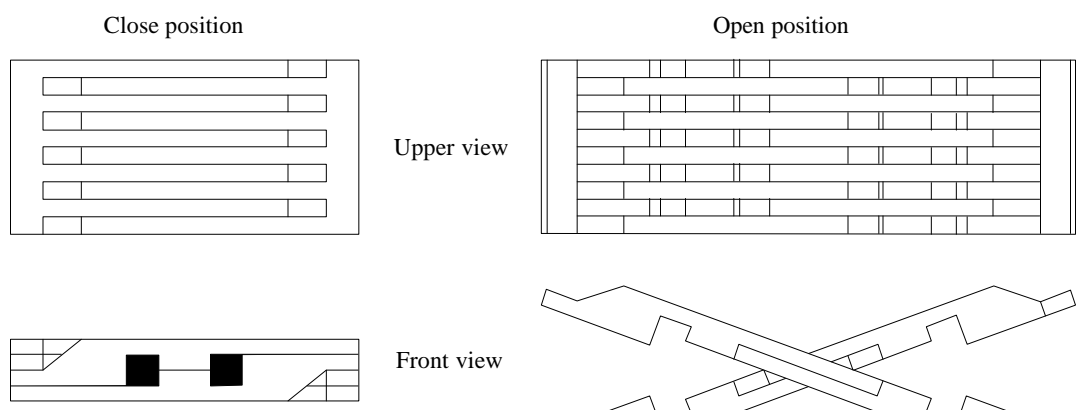

Front view
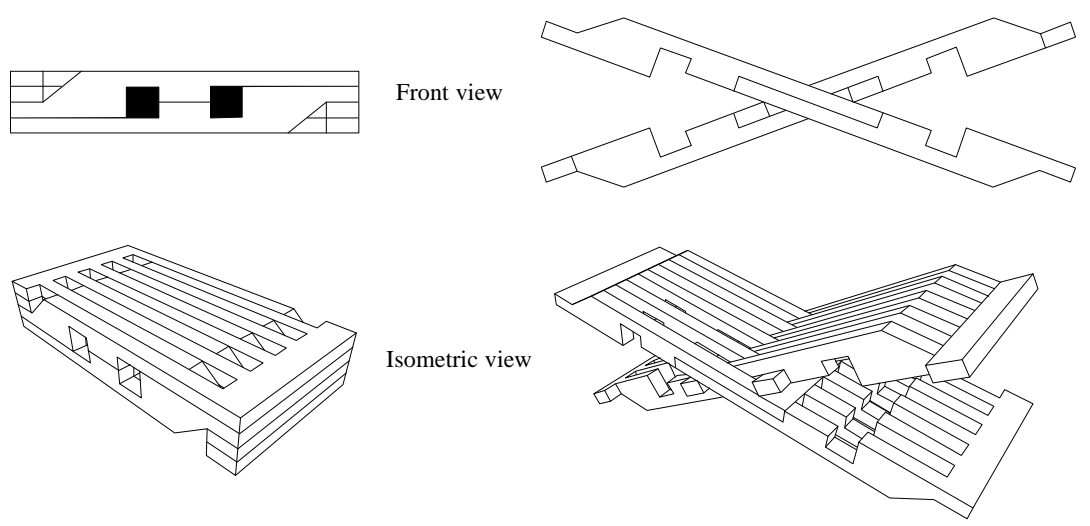

Fig. 5: Illustration of layered rehal or rehal berlapis plan (Mohd Zaki Mohd Ja'affar, Institut Latihan Perindustrian Kuala Terengganu) 
The design and technique of layered rehal or rehal berlapis are quite similar with traditional bookstand from Uzbekistan known as laukh. In an interview on December 3, 2016, Mirsaid Nigmatov, a woodcarver from Uzbekistan explained that laukh can be found in several layers, either four, six or eight. In terms of decoration, laukh is usually carved or painted with floral motifs. The production of laukh utilises natural resources from the country, especially, walnut wood. In contrast to local products, the sample of this study showed that layered rehal or rehal berlapis are prepared with four layers without ornamentation or carving and uses local woods, especially chengal.

\section{CONCLUSION}

Traditional rehal in the East Coast of Peninsular Malaysia usually made of wood. Among local carpenters and carvers, chengal is the most preferred species in woodworking including in rehal making. There are three types of rehal found which differ in terms of techniques. They are known as rehal selak, hinged rehal or rehal berjejari and layered rehal or rehal berlapis. Rehal selak make use of a technique known as tanggam which is a joinery technique adopted from Malay architecture. Hinged rehal or rehal berjejari uses hinges that allow the boards to be folded. Layered rehal or rehal berlapis applied sliding technique to open and close the furniture. Several techniques used in rehal making shows the ability of Malay craftsmen in adapting various skills and technology in their works with adjustments and improvements that suits local style.

\section{ACKNOWLEDGEMENT}

This research was carried out with the assistance of the research grantDPP-2018-099. Therefore, we would like to express our gratitude to Universiti Kebangsaan Malaysia (UKM) for the research grant awarded.

\section{REFERENCES}

Hughes, T.P., 1895. A Dictionary of Islam: Being a Cyclopedia of the Doctrines, Rites, Ceremonies and Customs Together with the Technical and Theological Terms of the Muhammadan Religion. W.H. Allen \& Company, London, UK., Pages: 750 .

Kuhnel, E., 1971. The Minor Arts of Islam (Translated by K. Watson). Cornell University Press, New York, USA., Pages: 255.

Kurz, O., 1972. Folding Chairs and Koran Stands. In: Islamic Art in the Metropolitan Museum of Art, Ettinghausen, R. (Ed.). Metropolitan Museum of Art, New York, USA., ISBN:9780870991110, pp: 299-214.

Noor, F.A., E. Khoo and D. Lok, 2003. Spirit of Wood: The Art of Malay Woodcarving. Tuttle Publishing, Singapore, ISBN-13: 9780794601034 , Pages: 176.

Wahab, M.R.A., Z. Ramli, M.A.A. Samad, N.Z. Harun, M.N.M. Nasir and S.S. Masdey, 2018b. Ancient maritime symbols in Malay traditional boat in the East Coast, Peninsular Malaysia. Plann. Malaysia, 16: 372-380.

Wahab, M.R.A., Z. Ramli, N.N.A. Ismail, N. Abu Bakar and W.N.S.W. Azhar, 2018a. Symbolism in traditional Malay boat crafting in the East Coast. Plann. Malaysia, 16: 294-302.

Zakaria, R.M.A. and Z. Ramli, 2016a. Physical analysis of the 19th century AD East Coast Red Qur'an Bindings. Mediterr. J. Soc. Sci., 7: 390-397.

Zakaria, R.M.A. and Z. Ramli, 2016b. Significance of garden design decoration in Islamic bookbinding. Islamic Q., 60: 529-545.

Zakaria, R.M.A. and Z. Ramli, 2018. Nondestructive analysis tests to evaluate the property of Qur'an bindings. Al Shajarah, 23: 425-439. 